\title{
Reply to Huemer on the Consequence Argument
}

DOI:

10.1215-111-2-235

\section{Document Version}

Accepted author manuscript

Link to publication record in Manchester Research Explorer

\section{Citation for published version (APA):}

Beebee, H. (2002). Reply to Huemer on the Consequence Argument. Philosophical Review, 111(2), 235-241. https://doi.org/10.1215-111-2-235

\section{Published in:}

Philosophical Review

\section{Citing this paper}

Please note that where the full-text provided on Manchester Research Explorer is the Author Accepted Manuscript or Proof version this may differ from the final Published version. If citing, it is advised that you check and use the publisher's definitive version.

\section{General rights}

Copyright and moral rights for the publications made accessible in the Research Explorer are retained by the authors and/or other copyright owners and it is a condition of accessing publications that users recognise and abide by the legal requirements associated with these rights.

\section{Takedown policy}

If you believe that this document breaches copyright please refer to the University of Manchester's Takedown Procedures [http://man.ac.uk/04Y6Bo] or contact uml.scholarlycommunications@manchester.ac.uk providing relevant details, so we can investigate your claim.

\section{OPEN ACCESS}




\section{Reply to Huemer on the Consequence Argument ${ }^{1}$}

Helen Beebee

Please do not cite this version. The published version is:

'Reply to Huemer on the Consequence Argument', Philosophical Review 111 (2002), 235-41

In a recent paper, Michael Huemer (2000) provides a new interpretation for ' $N$ ', the operator that occurs in Peter van Inwagen's Consequence Argument, ${ }^{2}$ and argues that, given that interpretation, the Consequence Argument is sound. I have no quarrel with Huemer's claim that the Consequence Argument is valid. I shall argue instead that his defence of its premises - a defence that allegedly involves refuting David Lewis's (1981) response to van Inwagen - is unsuccessful.

Following Huemer, let

$\mathrm{N}_{\mathrm{S}} p=$ No matter what $\mathrm{S}$ does, $p$

where

(No matter what $\mathrm{S}$ does, $p)=(p$, and for each action, $\mathrm{A}$, that $\mathrm{S}$ can perform, if $\mathrm{S}$ were to perform A, it would still be the case that $p$ ). (538)

' $\mathrm{N}_{\mathrm{S}} p$ ' is Huemer's replacement for van Inwagen's ' $\mathrm{N} p$ ', for which Huemer considers and rejects various alternative interpretations.

Huemer states the Consequence Argument thus (540):

1. $\left(\mathrm{P}_{0} \& \mathrm{~L}\right) \rightarrow \mathrm{P} \quad$ assumption

2. $\mathrm{N}_{\mathrm{S}} \mathrm{P}_{0} \quad$ premise

3. $\mathrm{N}_{\mathrm{S}} \mathrm{L}$ premise

4. $\mathrm{N}_{\mathrm{S}}\left(\mathrm{P}_{0} \& \mathrm{~L}\right) \quad 2,3$; rule $\beta^{*}$

5. $\mathrm{N}_{\mathrm{S}} \mathrm{P} \quad 1,4$; rule $\alpha^{*}$ 
where $\rightarrow$ is entailment, $\mathrm{P}_{0}$ is a true proposition describing the complete state of the universe at some time in the distant past, $\mathrm{L}$ is the conjunction of all the laws of nature, $\mathrm{P}$ is a proposition "describing any occurrence after the time at which the state described by $\mathrm{P}_{0}$ held" (526), and $\mathrm{S}$ is any arbitrarily chosen person.

Assumption (1) is a statement of determinism, and the conclusion (5) states that, for any $\mathrm{S}$ and $\mathrm{P}$, no matter what $\mathrm{S}$ does, $\mathrm{P}$. In other words, the conclusion of the argument is that whatever will be will be - no matter what anybody does. Granting that this is incompatible with anyone having free will, the argument, if sound, establishes that free will and determinism are incompatible.

Huemer argues (in section 1.2 ) that rule $\alpha^{*}$ and rule $\beta^{*}$ are equivalent to van Inwagen's rule $\alpha$ and rule $\beta,{ }^{3}$ and that, given his reading of ' $N$ ', those rules are valid (section 4). All well and good. The question I am concerned with, and the question Huemer addresses in section 5 of his paper, is whether or not, on his interpretation of ' $N$ ', premises (2) and (3) withstand Lewis's attack on the Consequence Argument.

Assuming that Huemer's version of the Consequence Argument is valid, in order to escape its conclusion the traditional compatibilist ${ }^{4}$ has to deny at least one of premises (2) and (3): she has to claim either that we can "do something about" the past or that we can do something about the laws (or both). According to Lewis, premise (3) is false: deterministic agents can "do something about" the laws. Lewis argues that there is a harmless sense in which we can do something about the laws ("render the laws of nature false in the weak sense", in his terminology) - a sense that survives van Inwagen's arguments to the contrary, since van Inwagen establishes only the uncontroversial claim that we cannot render the laws of nature false in a "strong" sense.

Huemer notes that Lewis denies premise (3), but does not attempt to meet Lewis's objection to that premise. Rather, Huemer concentrates on defending premise (2) against 
Lewis. However, as I shall argue, Huemer's defence of premise (2) fails to undermine a Lewis-style response to the Consequence Argument, since a Lewis-style compatibilist need not deny premise (2) in the first place.

In order to see what the Lewis-style compatibilist ought to say about premise (2), we need to rehearse briefly Lewis's compatibilist position. Lewis assumes determinism and claims that he is nonetheless able to raise his hand:

I have just put my hand down on my desk. That, let me claim, was a free but predetermined act. I was able to act otherwise, for instance to raise my hand. But there is a true historical proposition $\mathrm{H}$ about the intrinsic state of the world long ago, and there is a true proposition L specifying the laws of nature that govern our world, such that $\mathrm{H}$ and $\mathrm{L}$ jointly determine what I did. They jointly imply the proposition that I put my hand down. They jointly contradict the proposition that I raised my hand. Yet I was free; I was able to raise my hand. The way in which I was determined not to was not the sort of way that counts as inability. (1981, 291-2)

More generally, Lewis claims that there are some acts that he is able to perform (raise his hand, for example), such that, were he to perform any of them, L would be false. This claim follows from the particular claim - that he is able to raise his hand - together with his analysis of counterfactuals. Given determinism, the closest possible world where Lewis raises his hand must be a world where either facts about the very distant past are different or the laws of nature are different (or both). But on his analysis of counterfactuals, a minor violation of laws counts against closeness less than does a difference in facts throughout the whole of the past. Hence, the closest world where he raises his hand will be one whose past matches the actual world's past until fairly close to the relevant time, whereupon a "divergence 
miracle" - a violation of the actual laws - occurs, enabling him to raise his hand at that world. ${ }^{5}$ Lewis denies, however, that the act of hand-raising would itself be a miracle: he denies that we are able to perform such "law-breaking acts". Rather, the violation of the actual laws would occur slightly before the hand-raising. ${ }^{6}$ Hence Lewis subscribes to what he calls the "Weak Thesis", (WT):

(WT): I am able to do something such that, were I to do it, a law of nature would be broken,

but denies the "Strong Thesis", (ST):

(ST) I am able to break a law. [That is to say, I am able to do something such that, were I to do it, my act would itself be or cause a law-breaking event. $]^{7}$

In response to Lewis, Huemer says:

Lewis claims that, if A is any action I do not perform, if I were to perform A, some actual law of nature would be false and the past would be different from the actual past. In his terminology, my performing A would render a law false in the weak sense. This is because, if I performed act A, it would have to have been because a divergence miracle occurred shortly before my performance of A.

Now, it is not entirely implausible that this is true, if determinism is true. But what is entirely implausible is that, in spite of this, I might be perfectly free to do A. If, in order for me to do A, something would have to have happened five minutes ago 
(or a year ago, or five seconds ago, or whatever) that did not in fact occur, then I cannot now do A. (541-2)

Unfortunately, however, Huemer here fails to distinguish between two different things that "past", in the present context, can mean. Lewis does indeed claim that I am (now) able to perform some act A such that, if I were to perform A (when in fact I do not do so), the past relative to the time of $A$ would be different - that is to say, such that a miracle would occur prior to the time at which A would occur. But that claim does not entail that I am now able to perform any act $\mathrm{A}$ such that, if I were to perform $\mathrm{A}$, the past relative to now would be different.

To see the distinction clearly, we need to get our time-indexing straight. We can distinguish two theses, each of which entails (WT) - the thesis to which Lewis explicitly subscribes.

(WT1) For some times $t_{1}$ and $t_{2}$, where $t_{2} \geq t_{1}$, and for some non-actual act A: I am able, at $t_{1}$, to do $\mathrm{A}$ at $t_{2}$, and, were I to do $\mathrm{A}$ at $t_{2}$, a law would have been broken prior to $t_{2}$ (and hence the past-relative-to- $t_{2}$ would have been different).

(WT2) For some times $t_{1}$ and $t_{2}$, where $t_{2} \geq t_{1}$, and for some non-actual act A: I am able, at $t_{1}$, to do $\mathrm{A}$ at $t_{2}$, and, were I to do $\mathrm{A}$ at $t_{2}$, a law would have been broken prior to $t_{1}$ (and hence the past-relative-to- $t_{1}$ would have been different).

Lewis holds (WT1): I am able to do something A such that, were I to do it, a law would have been broken prior to the time of A. But nothing he says suggests that he holds (WT2). A Lewis-style compatibilist need not be committed to the claim that there is ever a time $t$ such 
that any deterministic agent is able, at $t$, to perform an act A at or after $t$, such that were they to do A, the past relative to $t$ would be different to the actual past relative to $t$.

Huemer may well be right that "if, in order for me to do A, something would have to have happened five minutes ago (or a year ago, or five seconds ago, or whatever) that did not in fact occur, then I cannot now do A". If he is right, then (WT2) is indeed false. But the Lewis-style compatibilist need not (and probably should not) be committed to (WT2). So Huemer's attempt to show that (WT2) is false does nothing to undermine Lewis's position.

Consider an example Huemer uses to motivate the thesis he is trying to establish:

Suppose that you are a doctor in the emergency room of a hospital, where a heart attack victim has just been brought in. Suppose you know, as a matter of the laws of biochemistry and the physiology of the human body, that in order for a heart attack patient to be revived, CPR must be administered within three minutes of the time of the heart attack. Suppose you also know that for this patient, four minutes have already elapsed, during which the patient did not receive CPR. You would obviously be correct to conclude that, at this point, you cannot revive the patient. (542)

The Lewis-style compatibilist can accept all this. All it shows is that (WT2) is false. But this leaves the status of (WT1) unchallenged. Suppose you, as the imagined doctor, know that for this patient, two minutes have already elapsed, during which the patient did not receive CPR. Then you would be incorrect to conclude that, at this point, you cannot revive the patient. (It might, of course, be true that you cannot revive the patient. But it would be wrong - not to mention criminally negligent - of you to infer it from the information just given.) 
According to any sensible theory of abilities, the question of whether you have the ability at $t_{1}$ to perform some act $\mathrm{A}$ at some later time, $t_{2}$, depends on what the circumstances are at $t_{l}$. The ability to perform $\mathrm{A}$ at $t_{2}$ is an ability that one might have at earlier times, but subsequently lose as time progresses. As a feigned Lewis-style compatibilist, I hold that even if determinism is true, I was probably - that is to say, so far as I know - able, when I was twelve years old, to become a surgeon by the age of thirty. By the time I was, say, twentyfive, I had lost that ability: circumstances were such that I could not possibly complete the required training quickly enough. By the time I was twenty-five (at time $t$ ), in order to become a surgeon by the age of thirty, the past (relative to $t$ ) would have to have been different. So I was not able, at $t$, to become a surgeon by the age of thirty. And, being now over the age of thirty, I am certainly unable now to (have) become a surgeon by the age of thirty.

According to incompatibilists, if determinism is true we are never able to do otherwise than what we actually do. So according to the incompatibilist, assuming determinism, I never had the ability to become a surgeon by the age of thirty - not even when I was twelve. The Lewis-style compatibilist only needs to hold (WT1) in order to avoid this alleged consequence of determinism: she only needs to hold that there was a time (when I was twelve, say) such that I was able, at that time, to bring things about after that time that would have resulted in my becoming a surgeon by the age of thirty. She need not additionally hold that I was able at the age of twenty-five, say, to become a surgeon by the age of thirty; that is, she need not hold (WT2). A compatibilist might hold that additional claim, but such a view would, as Huemer argues, be implausible. Huemer's rejection of (WT2) is perfectly reasonable, but it does nothing to block the Lewis-style compatibilist's response to the Consequence Argument, since the Lewis-style compatibilist need not be committed to (WT2). 
To believe premise (2) of the Consequence Argument is to believe in the fixity of the past $^{8}$. It is to believe that I cannot now do anything about what has already happened; it is not to believe that I cannot do anything about what will, at some time in the future, already have happened. After all, some of what is past-relative-to-the-future is now in the future, and not in the past. So to believe that we can do something about that is not to deny the fixity of the past, but only the fixity of the future. The Lewis-style compatibilist holds that some agents in some deterministic worlds are able, at $t$, to do something about what happens after $t$. She is not thereby committed to holding that such agents are ever able to do something about what happens prior to $t$.

Premise (2) of the Consequence Argument $-\mathrm{N}_{\mathrm{S}} \mathrm{P}_{0}-$ says, "no matter what we do, $\mathrm{P}_{0}$ ", which in turn cashes out as " $\mathrm{P}_{0}$, and for each action $\mathrm{A}$ that $\mathrm{S}$ can perform, if $\mathrm{S}$ were to perform A, it would still be the case that $\mathrm{P}_{0}$ ". $\mathrm{P}_{0}$ is a true proposition describing the complete state of the universe at some time in the past (indeed, the distant past). If we were to read 'past' here as 'past relative to A' - and drop the 'distant' - we would indeed have a premise that the Lewis-style compatibilist would deny. But such a premise would presuppose the fixity of the future, which is just what the Consequence Argument is supposed to establish (assuming determinism).

Given this, the Lewis-style compatibilist need have no quarrel with premise (2) under a reasonable interpretation - of Huemer's reformulation of the Consequence Argument. In order to show that his reformulation meets Lewis's objection, Huemer would have to defend premise (3) - the premise which the Lewis-style compatibilist does deny. He does not attempt to do this; hence he fails to show that Lewis-style compatibilism does not represent an adequate response to the (reformulated) Consequence Argument. 


\section{Bibliography}

Fischer, J.M. 1994. The Metaphysics of Free Will. Oxford: Blackwell.

Huemer, M. 2000. "Van Inwagen's Consequence Argument." Philosophical Review 109: $525-544$.

Lewis, D.K. 1979. “Counterfactual Dependence and Time’s Arrow.” Nous 13: 455-476.

Lewis, D.K. 1981. "Are We Free to Break the Laws?" Theoria 47: 113-121, reprinted in his Philosophical Papers Volume II, 291-298. New York: OUP.

Van Inwagen, P. 1983. An Essay on Free Will. Oxford: Clarendon Press.

\section{Endnotes}

${ }^{1}$ I am grateful to an anonymous referee for this journal for some helpful comments and suggestions.

${ }^{2}$ See van Inwagen 1983, Chapter 3.

${ }^{3}$ In the sense that $\alpha^{*}$ and $\beta^{*}$ are both valid iff $\alpha$ and $\beta$ are both valid. The rules are as follows: Rule $\alpha$ : From $p$, deduce $\mathrm{N} p$. Rule $\beta$ : From $\mathrm{N} p$ and $\mathrm{N}(p \supset q)$, deduce $\mathrm{N} q$. Rule $\alpha^{*}$ : From $\mathrm{N} p$ and $p \rightarrow q$, deduce $\mathrm{N} q$. Rule $\beta^{*}$ : From $\mathrm{N} p$ and $\mathrm{N} q$, deduce $\mathrm{N}(p \& q)$.

${ }^{4}$ By 'traditional compatibilist', I mean the kind of compatibilist who accepts van Inwagen's claim that freedom requires the ability to do otherwise than what one actually does. Traditional compatibilism contrasts with what John Martin Fischer calls 'semicompatibilism', a version of compatibilism that accepts that agents in deterministic worlds cannot do otherwise than what they actually do, but denies that this compromises their freedom; see Fischer 1994, Chapters 7 and 8.

${ }^{5}$ See Lewis 1979. 
${ }^{6}$ See Lewis 1981, 294-295.

${ }^{7}$ See Lewis 1981, 293.

${ }^{8}$ See Fischer 1994, Chapter 3, especially 78-83, for a careful formulation and discussion of this principle. 